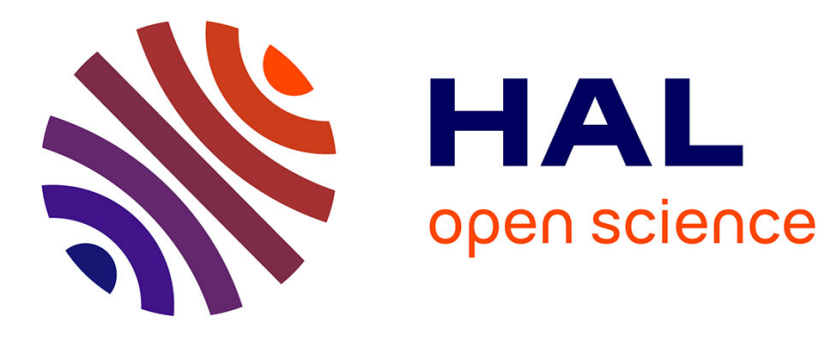

\title{
New Hippotragini (Bovidae, Mammalia) from the late Miocene of Toros-Menalla (Chad)
}

Denis Geraads, Cécile Blondel, Andossa Likius, Hassan T. Mackaye, Patrick Vignaud, M. Brunet

\section{- To cite this version:}

Denis Geraads, Cécile Blondel, Andossa Likius, Hassan T. Mackaye, Patrick Vignaud, et al.. New Hippotragini (Bovidae, Mammalia) from the late Miocene of Toros-Menalla (Chad). Journal of Vertebrate Paleontology, 2008, 28 (1), pp.231-242. hal-00265413

\section{HAL Id: hal-00265413 \\ https://hal.science/hal-00265413}

Submitted on 20 Nov 2009

HAL is a multi-disciplinary open access archive for the deposit and dissemination of scientific research documents, whether they are published or not. The documents may come from teaching and research institutions in France or abroad, or from public or private research centers.
L'archive ouverte pluridisciplinaire HAL, est destinée au dépôt et à la diffusion de documents scientifiques de niveau recherche, publiés ou non, émanant des établissements d'enseignement et de recherche français ou étrangers, des laboratoires publics ou privés. 
NEW HIPPOTRAGINI (BOVIDAE, MAMMALIA) FROM THE LATE MIOCENE OF TOROS-MENALLA (CHAD)

DENIS GERAADS ${ }^{1}$, CECILE BLONDEL ${ }^{2}$, ANDOSSA LIKIUS ${ }^{3}$, HASSANE TAISSO MACKAYE $^{3}$, PATRICK VIGNAUD $^{2}$, MICHEL BRUNET $^{2}$

\footnotetext{
${ }^{1}$ CNRS UPR 2147, 44 rue de l'Amiral Mouchez, 75014 Paris, France;

${ }^{2}$ IPHEP, CNRS UMR 6046, Université de Poitiers, 40 Avenue du Recteur Pineau, 86022 Poitiers cedex, France;

3 Département de Paléontologie, Université de N’Djamena, BP 1117, N’Djamena, Chad
}

Corresponding author: Denis Geraads, CNRS UPR 2147, 44 rue de l'Amiral Mouchez, 75014 Paris, France ; < dgeraads@ivry.cnrs.fr $>$.

RH: GERAADS ET AL.-HIPPOTRAGINI FROM THE LATE MIOCENE OF CHAD 
ABSTRACT-Until now, the pre-Pleistocene record of the bovid tribe Hippotragini was rather poor. We describe here two new taxa from the late Miocene of Toros-Menalla in northern Chad, which yielded the earliest known hominid, Sahelanthropus tchadensis. Tchadotragus sudrei n.gen. n.sp. is known by complete skulls and numerous horn-cores. It has typical hippotragine features such as long slender, curved horn-cores, weak cranial flexure, large frontal sinus, and hippotragine-like dentition, and is here taken as a basal member of the tribe, branching before the divergence between Oryx-Praedamalis and Hippotragus s.1. Saheloryx solidus n.gen. n.sp. is less well-known; it differs mainly by the lack of sinus in the frontal and horn-cores, shorter horncores, and rounded brain-case, but it shares with Tchadotragus a large number of features that prompt us to classify it also at the base of the hippotragine tree, perhaps as the sister-taxon of Tchadotragus.

No other African taxon looks like Saheloryx, and the only one similar to Tchadotragus is from Sahabi, Libya. The abundance of hippotragines sharply distinguishes Toros-Menalla from the East African late Miocene bovid faunas. 


\section{INTRODUCTION}

Since 1994, the "Mission Paléoanthropologique Franco-Tchadienne" has conducted paleontological field research in the Djurab region of Northern Chad, leading to the discovery of over 500 fossil vertebrate localities, most of them ranging in age from the late Miocene to the lower Pliocene, that help filling a wide geographic gap in the African fossil record. The major fossiliferous areas are Koro-Toro, with middle Pliocene strata (age estimated by biochronology at 3-3.5 Ma), which yielded the first australopithecines West of the Rift (Brunet et al., 1995, 1996), Kollé (Brunet et al., 1998), lower Pliocene (age estimated by biochronology at 4-4.5Ma), Kossom Bougoudi (Brunet and M.P.F.T., 2000), with Mio- Pliocene boundary faunas (age estimated by biochronology at ca.5.5Ma), and Toros-Menalla, which yielded the earliest known hominid (Brunet et al., 2002), of late Miocene age, ca.7 Ma (Vignaud et al., 2002; Brunet et al., 2005).

In all these deposits, the Bovidae constitute a large proportion of the faunal remains, as in other African sites of this time-period. Those from Koro-Toro have been described previously (Geraads et al., 2001). Here we describe two new taxa, ascribed to the tribe Hippotragini, from several localities of the anthracotheriid unit of Toros-Menalla (TM) (Vignaud et al., 2002), including TM266, type-locality of Sahelanthropus tchadensis. Other bovids, which include bovines, rare boselaphines, Aepyceros, gazelles, and numerous reduncines, will be described later. Extensive sand-dunes prevent direct stratigraphic correlation between localities, but their homogeneous faunal contents suggest that all localities are roughly contemporaneous; further research is in progress to refine their precise stratigraphic correlation. All specimens belong to the "Département des Collections" of the Centre National d'Appui à la Recherche (CNAR), N'Djamena, Chad. 


\section{SYSTEMATIC PALAEONTOLOGY}

Family BOVIDAE Gray, 1821

Sub-family HIPPOTRAGINAE Sundevall in Retzius and Lovén, 1845 (see Grubb, 2001)

Tribe HIPPOTRAGINI Sundevall in Retzius and Lovén, 1845

Genus TCHADOTRAGUS nov. gen.

Type-species-Tchadotragus sudrei nov.sp.

Diagnosis-That of the type and only species.

Derivatio nominis-from Tchad-, French name for Chad, and -tragus (Greek $\tau \rho \alpha ́ \gamma o \varsigma$, goat), a name frequently used for bovids.

Tchadotragus sudrei nov. sp.

Holotype-TM12-97-23, virtually complete skull, but lacking the premaxillae, right nasal, zygomatic arches, and most of the auditory region (Fig. 1-2).

Diagnosis-A primitive hippotragine of medium size, with a braincase slightly inclined on the splanchnocranium and broad over the mastoids, both halves of occipital surface facing partly laterally, a basioccipital with strong anterior tuberosities not reaching the level of the foramen ovale, large orbits with very prominent rims, a short face with a small jugal and a short and deep lacrymal bone, a large diffuse ante-orbital fossa, a relatively large ethmoidal fissure, premaxillae not contacting nasals, long slender curved horn-cores with some sigmoid curvature in antero-dorsal view, usually without transverse ridges, uprightly inserted and close to the midline, a large sinus in the pedicle, rather small supraorbital foramina, molar pattern simpler than in modern hippotragines, and premolars neither shortened nor enlarged. 
Derivatio nominis-In honour of our colleague and friend Dr Jean Sudre (EPHE, Montpellier), who found the holotype.

Material-There are about 85 horn-cores and skull pieces of T. sudrei. Among the ca. 450 mandibular and maxillary pieces that are assignable either to the same species or to the other taxon described below, only the mandibles TM266-01-177 and TM301-02-01 are definitely of T. sudrei, as they are associated with horn-cores. The identification of other specimens is discussed further down.

Description of the holotype-The cranium is almost complete except for the right nasal and both premaxillae. During fossilization, the maxilla was shifted upwards, and slightly rotated, crushing the jugal and lachrymal areas. All these bones were therefore cleaned and separated, and the facial part of the cranium reconstructed. Some imperfections remain, but the present condition and especially the relationship of the neurocranium and splanchnocranium are certainly very close to the real ones.

The skull is of medium size (Tab. 1), comparable to those of Gazella granti or Kobus kob. Its most noticeable feature is the length and slenderness of the horn-cores which are curved backwards, more strongly so in the middle part, but with a distal part that is even very slightly curved upwards. They are inserted above the orbits, not very far apart, and situated upright (the angle between their posterior border and the skull roof is greater than $90^{\circ}$ ). The divergence is weak at the base but increases upwards to decrease again near the tip; thus they have a weak but distinct graceful torsion. There is no hint of a keel or of transverse ridges. The cross section of each horn-core is moderately compressed (Tab. 1-2; Fig. 1F), with some flattening of the lateral surface, and the maximum transverse diameter is situated posteriorly; thus, the shape of the crosssection is that of a rounded triangle. Its main antero-posterior axis is oblique in respect to the sagittal plane. 
The face is moderately bent on the cranial axis, the fronto-nasal profile being inclined at an angle of $130^{\circ}$ on the parietal one. In lateral view, the base of the occipital condyles is approximately at the same level as the tooth-row. A short length of the suture of the premaxilla with the maxilla is preserved; it shows that a wide gap separated the former bone from the nasals, of which only the narrow posterior part of the left one is preserved. There is an extensive anteorbital fossa, but none of its limits is clear. The infra-orbital foramen is located high above P3. The lacrymal bone is large and deep (Fig. 2). There is a rather small and narrow ethmoidal vacuity, but it is larger than in modern hippotragines and free from bone internally. The contribution of the maxilla to its anterior border must have been very limited, as the large lacrymal bone certainly came very close to the nasal at this point. The jugal has no great extension on the face. The orbits are large, and their rims are extremely salient, giving them an almost tubular shape. Between them, no depression surrounds the supraorbital foramina, and the frontals are rather flat; they are not elevated between the horn-cores. Both the inter-frontal and fronto-parietal sutures form slightly elevated rims, and are almost fused, although the animal was not very old. The elongate post-cornual fossa is faint and shallow. The braincase is long, with a flat top surface; its width increases posteriorly, and the skull is broad at the post-tympanic level (Tab. 1). The temporal crests are well-marked and approach rather closely posteriorly, so that the supraoccipital is not broader than long. The parietal is long, as it reaches the nuchal crest, and might even have had a very short contact with the mastoid; its central part is slightly raised in a V-shaped structure, also present in some other bovids, which Morales et al. (2003) thought to be a remnant of the ancestral sagittal crest. The area of insertion of the M. temporalis is long and trapezoidal. The top of the occipital has the shape of an inverted V; below it, the two halves of this bone belong to two different planes facing laterally as well as posteriorly, but their meeting line in the sagittal plane does not form a crest. The paroccipital processes are flattened, slightly 
curved medially, and directed posteriorly. The mastoid exposure is broad, but remains wholly behind the nuchal crest, mostly in the occipital plane, because the auditory region is anteroposteriorly short. The basioccipital has a long sagittal groove; the posterior tuberosities are quite strong; the anterior ones are long, but remain more posterior than the foramen ovale. The post glenoid foramen is large. The bulla is missing, and the petrous bone is much eroded. In the palate, the palatines are of moderate length (they extend as far as the anterior lobe of M2), and the foramina open at their suture with the maxilla. The anterior border of the choanae is at the same level (posterior lobe of M2) as the lateral indentations.

The teeth are large relative to skull size, and are moderately worn. On the lateral walls, the styles are moderately prominent; the ribs are pronounced and rounded. The molars are broad relative to their length; they have a central enamel island and an entostyle arising from the cingulum, connected to the rest of the occlusal surface on M1. The central valleys lack accessory spurs. The protocone is slightly pinched, at least on M2.

Referred specimens-Tchadotragus sudrei is the most common bovid at Toros-Menalla, but it would be superfluous to describe in detail the other specimens, none of which is as well preserved as the holotype. However, skull TM58-98-02, although slightly crushed transversely, is more complete, as it preserves part of the premaxillae, well-separated from the nasals, and the auditory bulla, large but narrow, probably not as an effect of crushing. The chief interest of the other specimens is to confirm the features of the holotype. Some variation occurs in the horncores, which can be slightly more divergent (e.g., TM38-98-01), straighter (e.g., TM100-00-01), or have faint transverse ridges (TM251-01-01). The amount of flattening also varies; the outline of the cross-section may be either more rounded, or the posterior face may be less rounded than the medial and lateral faces (in contrast to the type), or they can all be flattened, giving the crosssection a more triangular outline, but the degree of transverse compression is rather constant 
(index between 0.66 and 0.90 , mean 0.75 ), and slightly greater than in most modern Hippotragus. Broken horn-cores show that the pedicle is hollowed by an extensive sinus, usually undivided, extending about one $\mathrm{cm}$ into the base of the horn-core itself, and that antero-medial to it and the supraorbital canal, another sinus hollows the frontal bone. By their fully hollowed base and pedicle, horn-cores of Tchadotragus can easily be told from those of the next species, provided that the base is preserved.

Neither the distribution of the antero-posterior dimension nor that of the transverse one are significantly different from normal distributions (Shapiro-Wilk tests: resp. $\mathrm{W}=0.980, \mathrm{p}=$ 0.49 and $\mathrm{W}=0.987, \mathrm{p}=0.83, \mathrm{~N}=55)$, but the antero-posterior dimension displays a shortfall of values around the mean, suggesting that a weak sexual dimorphism might have been present, as in modern hippotragines (Klein, 1974). The lack of hornless skull supports this hypothesis, but only weakly, as hornless bovid skulls are extremely rare in the whole bovid collection from TM.

Teeth-There are a number of tooth-rows of the appropriate size to belong to Tchadotragus sudrei, but their detailed morphology is often obscured by breakage or weathering. Furthermore, despite careful attempts, it has proven impossible to tell their teeth apart from those of the next species, which can be expected to be slightly larger. The only associated set of upper and lower teeth is TM266-01-131 (from the Sahelanthropus site), that we assign to Tchadotragus sudrei because the morphology of the upper teeth closely matches that of the holotype. The lower premolars (Fig. 4F) are rather short, the paraconid is weak, the metaconid is slanting distally on p3 but transverse on $\mathrm{p} 4$, the talonid of which is short and separated by a deep labial groove from the trigonid. The lower molars have a moderate ectostylid, no goat fold, the labial lobes are slightly pinched, and the third lobe of $\mathrm{m} 3$ is labially offset. Less worn specimens (e.g., Fig. 4G) show that the teeth are hypsodont ( $\mathrm{m} 3$ is as high as it is long), with rounded or even blunt cusps, but with high relief, and that the metaconid of $\mathrm{p} 4$ is mesially shifted. The paraconid may be 
stronger and distinct from the parastylid in the middle and upper part of the crowns of $\mathrm{p} 3$ and $\mathrm{p} 4$, and there may be an incipient goat fold, at least on $\mathrm{m} 1$, but there is no clear association of these features that would allow to separate the two taxa. Table 3 shows that the larger specimens (TM153-01-10 and TM297-01-04) had relatively shorter premolars, and one might hypothesize that this reflects a taxonomic distinction, but from their molar lengths (71 and $75 \mathrm{~mm}$ ), the two specimens that are definitely of Tchadotragus (see Material) would then be assigned to different species. More specimens with their complete set of cheek-teeth are needed before both taxa can be told apart from their teeth.

Comparisons-There is no doubt that Tchadotragus belongs to the Hippotragini, as it shares a number of similarities with living members of this tribe: (1) a skull moderately bent on the facial axis; (2) horn-cores long, without keels, little or no flattening of the lateral or medial surfaces, usually without transverse ridges; (3) an ethmoidal fissure smaller than in most Reduncini, Tragelaphini or Antilopini; (4) high infra-orbital foramina; (5) hollowed frontals; (6) a small shallow post-cornual fossa; (7) a parietal reaching the nuchal crest, and perhaps contacting the mastoid; (8) a low and wide occipital; (9) a mastoid facing mostly posteriorly, even in its lower part; and (10) a basioccipital with strong anterior and posterior tuberosities, with a groove between them.

The tribe Hippotragini has a poor fossil record, besides the Pleistocene $H$. gigas, best known from East Africa (Gentry and Gentry, 1978; Harris, 1991), but also reported from Algeria (Geraads, 1981) and South Africa (Gentry and Gentry, 1978; Klein and Cruz-Uribe, 1991). Hippotragus gigas is more primitive than living Hippotragus by its tooth morphology, but the premolars are very short, there are large goat folds, and it further differs from Tchadotragus by its larger size, less upright horn-cores, and base of horn-core higher above the upper orbital rim; the 
facial characters are unknown. Hippotragus cookei Vrba, 1987, is a poorly known form, reported only from Makapansgat.

A horn-core from the late Miocene or earliest Pliocene of Sahabi, Libya, was referred to ?Hippotragus sp. by Lehmann and Thomas (1987). It is long and slender, but slightly less uprightly inserted than those from Chad. The backward curvature is also perhaps stronger than the average at Toros-Menalla, but it would certainly have been referred to T. sudrei if found there. Although more material from Sahabi would be welcome, we believe that this horn-core definitely documents Tchadotragus from Libya, confirming this biogeographic connection (Lihoreau et al., 2006).

No hippotragine is known from Lukeino and Mpesida (Thomas, 1980). From Lothagam, Harris (2003) reported a Hippotragus sp. which differs from all other species of this genus, and from Tchadotragus, by the low insertion of its horn-cores, but the material is poor, and the identification is debatable. In any case, hippotragines are quite rare at Lothagam, in sharp contrast to Toros-Menalla.

From Kanapoi, Harris et al. (2003) described as Hippotragini gen. indet. a horn-core fragment (KNM-KP-30361) that could as well be reduncine; however, at least one mandibular fragment is certainly hippotragine, but this tribe is certainly rare, as at Lothagam.

The genus Praedamalis includes two species: P. deturi Dietrich, 1950, from Laetoli and Hadar, and P. howelli Vrba and Gatesy, 1994, from Maka in the Middle Awash. All these occurrences are in the 3-3.7 Ma time-range, but the genus has also been reported from Lothagam (Harris, 2003). Praedamalis has nearly straight horn-cores, which are less inclined than in Oryx, but more so than in Hippotragus, and well-marked goat folds: thus, it is sharply distinct from Tchadotragus. 
From the Upper Siwaliks, Pilgrim (1939) erected the genus Sivatragus for his new species S. bohlini, added S. brevicornis as a second species, and included both of them in the Hippotragini. Gentry and Gentry (1978:352) suspected that the latter species "is not hippotragine at all". The type-frontlet has a very sharp fronto-parietal flexure, and the basal part of the horncores is swollen; both features remind of the Alcelaphini, and we believe that S. brevicornis fits better this tribe. Sivatragus bohlini resembles Tchadotragus by its braincase which is broad at the mastoid level and with strong temporal ridges, and by the prominent orbital rims. However, the braincase is shorter, its top surface is not flat, the occipital faces caudally (Pilgrim, 1939, pl. 2, fig. 3), the horn-cores are less upright, and their maximum width is less posterior. The face and most of the horn-cores being unknown, the comparisons cannot go much beyond this, but S. bohlini could be close to the ancestry of Hippotragus. Vrba and Gatesy (1994) even concluded from a parsimony analysis that it is more specifically related to the early Pleistocene $H$. gigas.

In the late Miocene of Europe, Asia, and North Africa, an array of antelopes centered on the genera Protoryx Major, 1891 and Pachytragus Schlosser, 1904 have some resemblance to Tchadotragus. Many authors (Solounias, 1981; Köhler, 1987; Bosscha Erdbrink, 1988; Bouvrain, 1994, 1997) considered Pachytragus as synonymous with Protoryx, and often linked them with the Hippotragini. Gentry, instead, repeatedly $(1971,2000,2003$; Gentry et al., 1999) insisted on their generic distinction, and on the caprine affinities of Pachytragus. Indeed, Tchadotragus, which is contemporaneous with the last representatives of Pachytragus, is a much better candidate for hippotragine ancestry. The following set of features shared by Pachytragus and modern hippotragines are also present in Tchadotragus; they are therefore clearly primitive for the whole group, and of no help to support exclusive Pachytragus-Hippotragini relationships: (1) some inclination of the face on the cranium; (2) a long braincase; (3) a small, shallow postcornual fossa; (4) wide posterior and strong anterior tuberosities on the basioccipital, with a 
longitudinal groove; and (5) pedicle and horn-core base hollowed by a large, dome-shaped, sinus. On the other hand, Tchadotragus has derived hippotragine features, absent in Pachytragus: (1) a braincase widening posteriorly; (2) long slender horn-cores; (3) rounded lingual walls on lower molars and labial walls on upper molars; (4) large entostyles and ectostylids; and (5) a bulbous metaconid on p4. By contrast, Pachytragus has several caprine features that are absent in Tchadotragus. They were discussed at length by Gentry (1971, 2000, 2003; Gentry et al., 1999); the tooth characters of Pachytragus, especially, are almost as different as possible from those of the hippotragines (very short premolars, weak or absent accessory columns, narrow styles and weak pillars on upper molars, flat labial walls of upper teeth and lingual walls of lower teeth). To these can be added (1) the tendency towards anterior keel development on the horn-core, never met in the Hippotragini, and (2) the strong bending of the face on the cranium, with a frontal between the horns which is much higher than the orbital rims; this occurs only in $H$. niger among the Hippotragini, and even in this species the base of the occipital condyle is not lower than the tooth-row.

The only feature shared by Pachytragus and Hippotragus, but not by Tchadotragus, is the central position of the maximum transverse diameter of the horn-core, although some Hippotragus also have a maximum diameter situated posteriorly. However, the triangular crosssection of most Tchadotragus horn-cores might be a secondary consequence of their being very long and curved, implying reinforcement of the posterior part. Thus, we do not believe that Tchadotragus is closely related to Pachytragus, nor that its ancestry should be searched in the Eastern Mediterranean.

In Africa, early forms are not well known, as the late Miocene African record is poor. Those referred to Caprotragoides Thenius, 1979, by Thomas $(1981,1984)$ were included by Azanza and Morales (1994) in their new genus Gentrytragus. Gentrytragus gentryi (Thomas, 
1981), from Ngorora, Kenya, has a skull which is not unlike that of Tchadotragus, with horncores uprightly inserted, transversely compressed and curved backwards, a weak post-cornual fossa, a braincase broadening posteriorly and only slightly angled on the face, and rather hypsodont teeth and short premolars. However, some of these features are probably primitive, and G. gentryi differs from Tchadotragus in that its cranial basis is shorter, the orbit smaller and more anterior, the horn-cores are also more anterior, their pedicle is not hollowed, the upper teeth have flatter lingual walls and no entostyle, the p4 may be fully molarized and the lower molars are alcelaphine-like by their rounded outline, reduced ectostylid, and lack of goat-fold. These tooth characters bring it closer to caprines or alcelaphines than to hippotragines. From the earlier site of Fort Ternan, Kenya, Gentrytragus thomasi Azanza and Morales, 1994 (described as ? Pseudotragus potwaricus by Gentry, 1970) has a more primitive $\mathrm{p} 4$, but its aegodont teeth are also unlike those of Tchadotragus and the Hippotragini.

\section{Genus SAHELORYX nov.gen.}

Type-species-Saheloryx solidus nov.sp.

Diagnosis-That of the type and only species.

Derivatio nominis-from Sahel-, the semi-arid belt south of the Sahara, and -oryx, a living hippotragine.

\section{Saheloryx solidus nov. sp.}

Holotype-TM108-00-08, cranium with bases of horn-cores (Fig. 4A-E).

Diagnosis-An hippotragine of rather large size, with a low, broad braincase, rounded in antero-posterior and transverse directions, a low occipital surface facing mainly posteriorly, a basioccipital with anterior tuberosities reaching the level of the foramen ovale, horn-cores uprightly inserted and wide apart, slightly divergent and slightly curved backwards, without 
transverse ridges, no sinus in frontal and horn-core pedicle, and supraorbital foramina in wide depressions, teeth similar to those of Tchadotragus.

Derivatio nominis-from Latin solidus, solid, not hollowed, because the horn-core bases are not pneumatized.

Material-About 75 horn-cores and skull pieces (measurements: Tab. 4), plus many mandibular and maxillary pieces.

Description-All crania are broken at the orbits, and the face is unknown, except for specimen TM38-98-02 showing a hint of shallow preorbital fossa. The horn-cores are inserted wide apart on a low pedicle, and are rather upright (in lateral view, the angle between their posterior border and the braincase is always close to $90^{\circ}$ ). They are moderately long, slightly divergent at the base and straight in anterior view, regularly and moderately curved in lateral view, without any twisting or spiraling, without keels or transverse ridges, but often with an antero-medial longitudinal groove. The cross-section is an almost regular oval, with slight lateral flattening (Fig. 4B); in contrast to Tchadotragus, it never tends to be triangular. Its long axis is not very oblique in respect to the sagittal plane, and the maximum transverse diameter is variable in position, but never very posterior.

The angle between the top of the braincase and the fronto-nasal line can be estimated at about $130^{\circ}$. The mid-frontal suture is raised as a low broad ridge. In profile, it is weakly convex antero-posteriorly between the horn-cores, but concave in its most anterior part. At this level, the frontal bone is deeply sunken on either side, antero-medially to the supraorbital foramina. The latter are large and open in triangular depressions. These last features are linked with the complete lack of sinuses, both in the frontal and pedicle. The orbital rims are moderately prominent. There is no post-cornual fossa, and no depression postero-medially to the horn-cores. 
The mid-frontal suture is fairly thick, and never fuses. The parieto-frontal suture is complex and indented medially.

The braincase is low and wide, especially in the supra-auditory region, which is splayed out laterally. Its upper profile is rounded, and continues in a regular curve that of the frontal bone. The temporal crests are strong anteriorly, along the parieto-frontal suture, but vanish posteriorly; the area of insertion of the M. temporalis is short and rounded. The occipital is strongly inclined, low, and very wide. Both halves are almost in the same plane, although the sagittal part is raised. The mastoid exposure is large, and its lower part faces mostly laterally, because the auditory region is antero-posteriorly stretched. The auditory foramen is small, especially on the holotype. The paroccipital processes may be very strong, as on cranium TM229-01-13, and are directed posteriorly. The postglenoid foramen is large. The basioccipital has moderate to large anterior tuberosities that reach the level of the foramen ovale; the posterior ones are wide but they are not prominent ventrally, and there is no clear sagittal groove.

No hornless cranium is known and we take this as an indication of the females being horned, but sexual dimorphism must have been weak, as the plots of the basal diameters of the horn-cores (Fig. 3) are not significantly different from normal distributions (Shapiro-Wilk tests: antero-posterior $\mathrm{W}=0.981, \mathrm{p}=0.71$; transverse $\mathrm{W}=0.989, \mathrm{p}=0.95, \mathrm{~N}=42$ ).

Comparisons - the main differences between these two bovid taxa of Toros-Menalla are summarized in Table 5.

These differences much exceed those between male and female of any other species of the Bovidae. In this family, the most obvious expression of sexual dimorphism, when present, lies in the horn-cores. In females, they are often absent or small; whenever they have a different morphology than those of the males (e.g., Antilopini), they are much smaller, whereas the difference here is in shape, not in size (Fig. 3). The frontal sinus may slightly differ between 
males and females of some species (Schaffer and Reed, 1972; Farke, 2007) but it is never extensive in one gender and absent in the other. Sexual dimorphism may also affect horn supporting structures and some cranial measurements (Hooijer, 1958; Cooke, 1996; Puzachenko and Rautian, 2001; Massei et al., 1993) but the set of differences listed above has no equivalent in any fossil or modern species. Therefore, the hypothesis that Saheloryx solidus and Tchadotragus sudrei are two sexes of one and the same species can be definitely ruled out. These differences are even far greater than those between two species of the same genus, especially those involving the proportions of the braincase, pneumatization of the frontal and related features. The crania of both taxa reflect two different building designs that cannot be accommodated within a single genus. Such a coexistence of two or more closely related bovid taxa of similar size and similar abundance is not a rare occurrence both in the modern and fossil records. Among the former, we may mention the topi and kongoni in the Serengeti, two species of Tragelaphus in the Kruger Park, both species of Hippotragus in the Okavango delta, or two species of Redunca in the Umfolozi Park, etc.; among the latter, two Alcelaphini at Ternifine (Geraads, 1981), four Reduncini in area 103 of the KBS Member of the Koobi Fora Formation (Harris, 1991), or four Alcelaphini at Olduvai BK II (Gentry and Gentry, 1978).

Among African tribes of large bovids, only the Reduncini and Tragelaphini normally have solid frontals and horn-core pedicels; Saheloryx is otherwise so different from the Tragelaphini that no detailed comparison is necessary, but a relationship with the Reduncini is less unlikely. It shares with members of this tribe: (1) a low and broad braincase, as in the large members of the genus Kobus; (2) the lack of sinus in the frontal and pedicle; and (3) the opening of the supraorbital foramen in depressions of the frontal. It differs by: (1) the probable presence of horns in females, whereas they are always absent in female reduncines; (2) the very upright insertion of the horn-cores, their weak divergence, and the lack of post cornual fossa; the lack of transverse 
ridges is also unlike most reduncines; (3) the moderate size of the anterior tuberosities of the basioccipital; and (4) the lack of derived reduncine features on the teeth, such as prominent pillars, pinching of the lobes, strong goat folds and entostyles/ectostylids, which are all quite clear, by contrast, in the Toros-Menalla reduncines. Thus, Saheloryx cannot be included in the Reduncini.

No bovid from Lothagam or Kanapoi resembles Saheloryx, but a comparison can be sought more to the North. Damalavus boroccoi Arambourg, 1959 is based upon a poorly preserved frontlet from the early late Miocene of Algeria; some of the few available features (short, much inclined horn-cores; narrow frontal) are quite unlike the Toros-Menalla hippotragines.

The Eurasiatic Palaeoryx Gaudry, 1861 (Gentry, 1970), mainly known from Turolian sites, is contemporaneous with, or slightly older than, Toros-Menalla. The main resemblances between Saheloryx and Palaeoryx are: (1) the general shape of the horn-cores; (2) the low and wide cranium, rounded dorsally; and (3) the slanting occipital, with both halves nearly in the same plane. However, the horn-cores of Saheloryx are relatively smaller, more upright, and more compressed. Another difference is the lack of frontal hollowing in the Chadian form, hence large sunken supraorbital pits. Upper teeth do not differ much, but those of Palaeoryx have definitely less rounded labial pillars. Its lower teeth are not known with certainty, but most of the largest dentitions from Pikermi and Samos in Greece probably belong to this genus (some others might be of Samokeros, as suggested by Solounias, 1981). Their teeth are broad relative to their length, they have more flattened lingual walls, there is no hint of a goat fold, the ectostylid is weak or absent, the p4 does not look antero-posteriorly compressed and the metaconid has an anteriorly directed flange that may even close the median valley. All these differences show that Saheloryx is not closely related to Palaeoryx. 
Pseudotragus capricornis Schlosser, 1904, from Samos, is a poorly known species, and the only known braincase (Schlosser, 1904, pl. 10, fig. 8) was apparently destroyed (Solounias, 1981:206). Both the female and very large male horn-cores are significantly more compressed than those of Saheloryx, and the supraorbital foramina open into narrow grooves. The teeth are similar to those of Palaeoryx, and the p4 further differs from those of Saheloryx by its shallow labial groove. Thus, just as for Tchadotragus, no bovid of the well-known Aegean late Miocene looks close to Saheloryx.

\section{Hippotragine Postcranials}

Many postcranial bones have been recovered from TM, some of them complete, but the similar size and probable close relations between the two common large species renders definite identifications impossible.

Humerus-Two types can be distinguished among the larger forms. In one, the distal articulation is conical, with the diameter of the lateral condyle much smaller than that of the medial part of the trochlea, which is somewhat rounded. This type resembles modern reduncines (and cervids), but it clearly belongs here either to Tchadotragus or to Saheloryx. In a second type, the distal articulation is more cylindrical, with the diameter of the lateral condyle not much smaller than that of the medial part of the trochlea. This type looks more what is found in modern alcelaphines and hippotragines, but the distal border of the lateral epicondyle is less oblique, the cylindrical shape is less clear than in hippotragines, and the lateral ridge caudal to the insertion of the extensor of the lateral digit is less caudal than in alcelaphines (see Peters et al., 1997, pl.6-7).

Radius-The lengths of three specimens can be estimated with reasonable precision. These are TM153-01-03 (length ca. 320), TM153-01-09 (length ca. 325) and TM55-98-04 (length $=290$ ). These values are not much smaller than those of two complete tibias and, unless all radii 
are from a different species than all tibiae, they imply that at least one of the larger TM forms had high forequarters.

Tibia-At the distal end, the median beak of the largest specimens is narrow, as in modern reduncines and hippotragines, and the cranial fibular facet is medially offset, a feature today known only in hippotragines (Peters et al., 1997, pl.16, character 73), but also present at Koro Toro in some other tribe (Geraads et al., 2001).

Calcaneus-The sustentaculum tali is weaker than in all modern African bovids, except alcelaphines, with its plantar border more cranial than that of the main part of the bone.

Metatarsus-The distal pulleys are not splayed out laterally, in contrast to modern alcelaphines and hippotragines. Non-tragelaphine African bovids are not otherwise very different for this bone.

On the whole, the relative lengths of the preserved bones (radius slightly longer than metatarsus, and not much shorter than tibia) best match those of Oryx among modern forms, but the similar size of the two taxa, and their similar frequency, as deduced from the horn-cores, imply that both were represented among the postcranial remains. This is confirmed by the cooccurrence of two different types of humeri, which also suggests that Tchadotragus and Saheloryx had somewhat different locomotory adaptations, but it is unlikely that the two genera had very different limb proportions.

\section{RELATIONSHIPS}

Based on the dataset of Vrba and Gatesy (1994), we assessed the relationships of Tchadotragus and Saheloryx with other Hippotragini by parsimony analysis (using an exhaustive search with Hennig86, command "ie"). We converted their qualitative estimates of the character 
states (e.g., "low", "high") into quantified ones, so as to keep, as far as possible, the same character states.

We made only a few changes to their data matrix, which includes an outgroup with hypothetical ancestral states (Tab. 6). We removed the Lothagam hippotragines (except Praedamalis) from the analysis, because their status is unclear. Specimen KNM-LT-188, used by Vrba and Gatesy (1994), is now referred to Aepyceros (Harris, 2003); among the most hippotragine-like fossils, KNM-LT-13010 has a deep post-cornual fossa, whereas KNM-LT23131 has none, and they must belong to different taxa. We also removed Wellsiana and Brabovus, as Vrba and Gatesy (1994) concluded that they are not hippotragine, and Sivatragus brevicornis, for the reasons given above. We removed their characters 4 (proportion of upper molars, because its estimate depends too much upon wear stage), and 6 (width of the premaxilla, because it is known in only very few terminals, and because the state in the outgroup is disputable), but we added seven more characters (numbers 24 to 30 in Tab. 6). Finally, we hypothesized that the angle of the face to braincase in the outgroup is low instead of high, which better conforms to the primitive condition in bovids.

The strict consensus tree (length $=59 ; \mathrm{ci}=66 ; \mathrm{ri}=81$ ) of the 18 shortest trees (length $=$ 58; $\mathrm{ci}=67 ; \mathrm{ri}=82$ ) shows Praedamalis + Oryx as the sister-group of Hippotragus + Sivatragus , a conclusion already reached by Vrba and Gatesy (1994), and Saheloryx + Tchadotragus as the sister-group of all others (Fig. 5, left). In a slightly longer tree that we favour (Fig. 5, right; length $=60 ; \mathrm{ci}=66 ; \mathrm{ri}=81)$, Saheloryx would be the sister-group of all other taxa, with Tchadotragus branching next, but probably not much later. The detailed lists of apomorphies supporting each clade are given in the caption to Fig. 5; the main ones, common to both trees, are as follows (character numbers in brackets). Node 1: metaconid of $\mathrm{p} 4$ bulbous (4); braincase more angled on the face (9); broader occipital (24); longer (21), larger (22), less compressed (15), and probably 
more upright (19) horn-cores. Node 3: goat-folds well developed on lower molars (26); longer face (30), with longer lachrymal bone (28), and a shallow or absent pre-orbital fossa (29), and perhaps an occipital facing caudally (27; parallel change in Saheloryx). Node 4: supra-orbital foramina wider apart (7); straighter (16) and more caudal (17) horn-cores. Node 5: horn-cores more divergent (23), with a less angled main axis of the cross-section (18), and perhaps an ethmoidal fissure blocked by bone (5). Node 7: braincase less inclined on the face (9); very long horn-cores (21). Node 8: horn-cores with strong backward curvature (16). Node 9: braincase less inclined on the face (9), strong temporal lines (10, parallel change in Tchadotragus + Saheloryx). Node 10: Y-shaped basal pillars (2); pinched medial lobes of upper molars (3); longer braincase (11).

Node 2 of the consensus tree is supported by strong temporal lines (10) and paroccipital processes slanting backwards (25), while Node 1' of our preferred tree (Fig. 5, right) is supported by acquisition of the frontal sinus ( 8 , which is thus non-homoplastic in this topology).

Both topologies are in good agreement with chronology. They also allow explaining the postcranial differences between the Chadian taxa and all modern hippotragines; if the latter form a monophyletic group not including the Miocene forms, their post-cranial characters may have been acquired recently, as was suggested at Koro-Toro for reduncines and alcelaphines (Geraads et al., 2001).

The cladograms presented here imply that the tribe Hippotragini is at least $7 \mathrm{Ma}$ old, and we believe that it is not much older. By contrast, by calibrating their super-tree of the ruminants, Hernández Fernández and Vrba (2005) have estimated the age of divergence between H. niger and H. equinus-H. leucophaeus at $8.8 \mathrm{Ma}$, and that of the Addax-Oryx and Hippotragus groups at about 11 Ma. This would put the divergence of Saheloryx and Tchadotragus back into the Middle Miocene; however, no definite Hippotragini is known at that time, nor in the first part of the 
Upper Miocene (Namurungule, Ngeringerowa, Nakali and Ngorora in Kenya; Bled Douarah and Jebel Krechem in Tunisia; Bou Hanifia and Oued Mya in Algeria). It would also imply a long ghost lineage leading to modern Hippotragus, as no definite Hippotragus is known in the MioPliocene (Langebaanweg in South Africa; Manonga in Tanzania; Lukeino, Mpesida and Lothagam in Kenya; the Middle Awash in Ethiopia; Nkondo in Uganda; Toros-Menalla and Kossom Bougoudi in Chad). We believe that this long list of localities without Hippotragini or Hippotragus comprises a reasonable case for "absence of evidence". Correspondingly, we suggest that the dates proposed by Hernández Fernández and Vrba (2005) are over-estimated, perhaps by a factor of two.

At a higher taxonomic level, there is now a consensus that the Hippotragini are closely related to the Alcelaphini, the Caprinae branching next (Gentry, 1992; Vrba and Schaller, 2000; Kuznetsova et al., 2002; Ropiquet and Hassanin, 2004; Price et al., 2005; Hernández Fernández and Vrba, 2005). Therefore, there is little doubt that both tribes originated in Africa, and Tchadotragus shows what a primitive hippotragine looked like, at a time when Pachytragus had already diverged towards the Caprini, from the ancestral Caprinae-Alcelaphini-Hippotragini stock.

Acknowledgments

We thank the Chadian Authorities (Ministère de l'Education Nationale de l'Enseignement Supérieur et de la Recherche, Université de N'djaména, CNAR), the Ministère Français de l'Education Nationale (UFR SFA, Université de Poitiers), Ministère de la Recherche (ANR ; CNRS : Départements EDD, SDV and ECLIPSE), Ministère des Affaires Etrangères (DCSUR, Paris and Projet FSP 2005-54 de la Coopération franco-tchadienne, Ambassade de France à N'djaména), the Région Poitou-Charentes, the NSF program RHOI (co-PI's F. C. Howell \& 
T. D. White), and the Armée Française, MAM and Epervier for logistical support. We are grateful to many colleagues and friends for their help. We thank also all the other MPFT members who joined us for field missions, and more especially S. Riffaut, X. Valentin and A. Bernet for technical support. We are most grateful to G. Florent and C. Noël for administrative MPFT guidance.

DG wishes to thank those who granted him access to collections in their care: M. Bertling (Paläontologisches Institut der Universität Münster), J. Cuisin, F. Renoult, C. Sagne and P. Tassy (Muséum National d'Histoire Naturelle, Paris), A. Currant (Natural History Museum, London), G. Daxner-Höck (Naturhistorisches Museum Wien), R. Marchant (Musée Cantonal de Géologie, Lausanne), E. Mbua and M. Muungu (National Museums of Kenya, Nairobi), as well as M.R. Palombo and R. Manni (Dipartimento di Scienze della Terra,Università di Roma) for sending him photos of the Sahabi hippotragine. The corrections and suggestions of R. Asher, JVP editor, and of two anonymous reviewers greatly improved the manuscript. 


\section{LITERATURE CITED}

Arambourg, C. 1959. Vertébrés continentaux du Miocène supérieur de l'Afrique du Nord. Publications du service de la carte géologique de l'Algérie, N.S., Paléontologie 4:1-159.

Azanza, B., and J. Morales. 1994. Tethytragus nov. gen. et Gentrytragus nov. gen., deux nouveaux Bovidés (Artiodactyla, Mammalia) du Miocène moyen. Relations phylogénétiques des Bovidés ante-vallésiens. Proceedings of the Koninklijke Nederlandse Akademie van Wetenschappen 97:249-282.

Bosscha Erdbrink, D. P. 1988. Protoryx from three localities East of Maragheh, NW Iran. Proceedings of the Koninklijke Nederlandse Akademie van Wetenschappen 91:101-159.

Bouvrain, G. 1994. Les gisements de Mammifères du Miocène supérieur de Kemiklitepe, Turquie: 9 - Bovidae. Bulletin du Muséum national d'Histoire naturelle, 4ème sér., C $16: 175-209$.

Bouvrain, G. 1997. Les Bovidés du Miocène supérieur de Pentalophos (Macédoine, Grèce). Münchner Geowissenschaftliche Abhandlungen 34:5-22.

Brunet, M., A. Beauvilain, Y. Coppens, E. Heintz, A. Moutaye, and D. Pilbeam. 1995. The first australopithecine recovered west of the Rift Valley (Koro Toro region, Republic of Chad). Nature 378:273-275.

Brunet, M., A. Beauvilain, Y. Coppens, E. Heintz, A. Moutaye, and D. Pilbeam. 1996. Australopithecus bahrelghazali, une nouvelle espèce d'Hominidé ancien de la région de Koro Toro (Tchad). Comptes rendus de l'Académie des Sciences, IIa 322:907-913.

Brunet M., A. Beauvilain, D. Geraads, F. Guy, M. Kasser, H. T. Mackaye, L. M. MacLatchy, G. Mouchelin, J. Sudre, and P. Vignaud. 1998. Tchad: découverte d'une faune de 
Mammifères du Pliocène inférieur. Comptes rendus de l'Académie des Sciences, Sciences de la Terre et des Planètes 326:153-158.

Brunet, M. and M.P.F.T. 2000. Chad : discovery of a vertebrate fauna close to the Mio-Pliocene boundary. Journal of Vertebrate Paleontology 20:205-209.

Brunet, M., F. Guy, D. Pilbeam, H. T. Mackaye, A. Likius, D. Ahounta, A. Beauvilain, C.

Blondel, H. Bocherens, J.-R. Boisserie, L. de Bonis, Y. Coppens, J. Dejax, C. Denys, P.

Duringer, V. Eisenmann, G. Fanone, P. Fronty, D. Geraads, T. Lehmann, F. Lihoreau, A.

Louchart, A. Mahamat, G. Merceron, G. Mouchelin, O. Otero, P. Pelaez-Campomanes,

M. Ponce de León, J.-C. Rage, M. Sapanet, M. Schuster, J. Sudre, P. Tassy, X. Valentin,

P. Vignaud, L. Viriot, A. Zazzo, and C. Zollikofer. 2002. A new Hominid from the Upper Miocene of Chad, Central Africa. Nature 418:145-151.

Brunet, M., F. Guy, D. Pilbeam, D. E. Lieberman, A. Likius, H. T. Mackaye, M. Ponce de León, C. P. E. Zollikofer, and P. Vignaud. 2005. New material of the Earliest Hominid from the Upper Miocene of Chad. Nature 434:753-755.

Cooke, H. B. S. 1996. Sexual dimorphism in Antidorcas recki from Bolt's Farm, South Africa, in the University of California collections; pp. 537-553 in K. M. Stewart and K. L. Seymour (eds.), Palaeoecology and palaeoenvironments of Late Cenozoic Mammals. University of Toronto Press, Toronto.

Dietrich, W. O. 1950. Fossile Antilopen und Rinder Äquatorialafrikas. Palaeontographica A 99:1-62.

Farke, A. A. 2007. Morphology, constraints, and scaling of frontal sinuses in the hartebeest, Alcelaphus buselaphus (Mammalia: Artiodactyla, Bovidae). Journal of Morphology 268:243-253.

Gaudry, A. 1861. Résultats des fouilles entreprises en Grèce sous les auspices de l'Académie. 
Comptes rendus hebdomadaires des séances de l'Académie des Sciences 52:238-241.

Gentry, A. W. 1970. The Bovidae (Mammalia) of the Fort Ternan fossil fauna; pp. 243-324 in L.

S. B. Leakey and R. Savage (eds.), Fossil Vertebrates of Africa, 2. Academic Press, London.

Gentry, A. W. 1971. The earliest goats and other antelopes from the Samos Hipparion fauna. Bulletin of the British Museum (Natural History) Geology 20:231-296.

Gentry, A. W. 1992. The subfamilies and tribes of the family Bovidae. Mammal Review 22:1-32. Gentry, A. W. 2000. Caprinae and Hippotragini (Bovidae, Mammalia) in the Upper Miocene; pp. 65-83 in E. S. Vrba and G. B. Schaller (eds.), Antelopes, deer and relatives : fossil record, behavioural ecology, systematics and conservation. Yale University Press, New Haven, Connecticut.

Gentry, A. W. 2003. Ruminantia (Artiodactyla); pp. 332-379 in M. Fortelius, J. Kappelman, S. Sen, and R. L. Bernor (eds.), Geology and Paleontology of the Miocene Sinap Formation, Turkey. Columbia University Press, New York.

Gentry, A. W., and A. Gentry. 1978. Fossil Bovidae (Mammalia) of Olduvai Gorge, Tanzania. Part I. Bulletin of the British Museum (Natural History) Geology 29:289-446.

Gentry, A. W., G. E. Rössner, and E. P. J. Heizmann. 1999. Suborder Ruminantia; pp. 225-258 in R. Bernor, V. Fahlbusch, and H.-W. Mittmann (eds.), The evolution of western Eurasian Neogene mammal faunas. Columbia University Press, New York.

Geraads, D. 1981. Bovidae et Giraffidae (Artiodactyla, Mammalia) du Pléistocène de Ternifine (Algérie). Bulletin du Muséum national d'Histoire naturelle, $4^{\text {ème }}$ sér., C 3:47-86.

Geraads D., M. Brunet, H. T. Mackaye and P. Vignaud. 2001. Pliocene Bovidae from the Koro Toro Australopithecine sites, Chad. Journal of Vertebrate Palaeontology 21:335-346. Grubb, P. 2001. Review of family-group names of living bovids. Journal of Mammalogy 82:374- 
388.

Harris, J. M. 1991. Family Bovidae; pp. 139-320 in J. M. Harris (ed.), Koobi Fora research project, 3: The fossil Ungulates: Geology, fossil Artiodactyls and palaeoenvironments. Clarendon Press, Oxford.

Harris, J. M. 2003. Bovidae from the Lothagam succession; pp. 531-558 in M. G. Leakey and J. M. Harris (eds.), Lothagam: the dawn of humanity in Eastern Africa. Columbia University Press, New York.

Harris, J. M., M. Leakey, and T. E. Cerling. 2003. Early Pliocene Tetrapod remains from Kanapoi, Lake Turkana Basin, Kenya; pp. 39-114 in J. M. Harris and M. G. Leakey (eds.), Geology and Vertebrate Paleontology of the Early Pliocene site of Kanapoi, Northern Kenya. Contributions in science, Natural History Museum of Los Angeles County 498:1-132.

Hernández Fernández, M., and E. S. Vrba. 2005. A complete estimate of the phylogenetic relationships in Ruminantia: a dated species-level supertree of extant ruminants. Biological reviews 80:269-302.

Hooijer, D. A. 1958. Sexual differences in the skull of fossil and recent bantengs. Mammalia $17: 73-75$.

Klein, R. G. 1974. On the taxonomic status, distribution and ecology of the blue antelope, Hippotragus leucophaeus (Pallas, 1766). Annals of the South African Museum 65:99143.

Klein, R. G., and K. Cruz-Uribe. 1991. The bovids from Elandsfontein, South Africa, and their implications for the age, palaeoenvironment, and origins of the site. African Archaeological Review 9:21-79.

Köhler, M. 1987. Boviden des türkischen Miozäns (Känozoikum und Braunkholen der Türkei. 
28). Paleontologia i Evolució 21:133-246.

Kuznetsova, M. V., M. V. Kholodova, and A. A. Luschekina. 2002. Phylogenetic analysis of sequences of the $12 \mathrm{~S}$ and $16 \mathrm{~S}$ rRNA mitochondrial genes in the family Bovidae: new evidence. Russian Journal of Genetics 38:942-950.

Lehmann, U., and H. Thomas. 1987. Fossil Bovidae (Mammalia) from the Mio-Pliocene of Sahabi, Libya; pp. 323-335 in N. T. Boaz, A. El-Arnauti, A. W. Gaziry, J. de Heinzelin, and D. D. Boaz (eds.), Neogene Paleontology and Geology of Sahabi. Alan Liss, New York.

Lihoreau, F., J.-R. Boisserie, L. Viriot, Y. Coppens, A. Likius, H. T. Mackaye, P. Tafforeau, P. Vignaud, and M. Brunet. 2006. Anthracothere dental anatomy reveals a late Miocene Chado-Libyan bioprovince. Proceedings of the National Academy of Sciences of the United States of America 103:8763-8767.

Major, C. F. 1891. Considérations nouvelles sur la faune des Vertébrés du Miocène supérieur dans l'île de Samos. Comptes-rendus de l'Académie des Sciences, Paris 113:608-610.

Massei, G., E. Randi, G. Markov, and P. Genov. 1993. Multivariate analysis of craniometric characters in Bulgarian chamois. Hystrix 5:17-29.

Morales, J., D. Soria, M. Pickford, and M. Nieto. 2003. A new genus and species of Bovidae (Artiodactyla, Mammalia) from the early Middle Miocene of Arrisdrift, Namibia, and the origins of the family Bovidae. Memoir Geological Survey of Namibia 19:371-384

Peters, J., W. Van Neer, and I. Plug. 1997. Comparative postcranial osteology of hartebeest (Alcelaphus buselaphus), scimitar oryx (Oryx dammah) and addax (Addax nasomaculatus), with notes on the osteometry of gemsbok (Oryx gazella) and Arabian oryx (Oryx leucoryx). Musée royal de l'Afrique centrale, Annales, Sciences zoologiques 280:1-83. 
Pilgrim, G. E. 1939. The Fossil Bovidae of India. Memoirs of the Geological Survey of India 26:1-356.

Price, S. A., O. R. P. Bininda-Emonds, and J. L. Gittleman. 2005. A complete phylogeny of the whales, dolphins and even-toed mammals (Cetartiodactyla). Biological reviews 80:445473.

Puzachenko, A. Y. and G. S. Rautian. 2001. Sexual dimorphism in the cranial characteristics of members of the genus Bison (Bovidae, Artiodactyla) and sex identification in Bison priscus. Palaeontological Journal 35:85-98.

Retzius, A. and S. N. Lovén. 1845. Bericht von Retzius und Lovén über Sundevall Abhandlung, betitelt: Methodische Uebersicht der wiederkäuenden Thiere. Arkiv Skandinavischer Beiträge zur Naturgeschichte 1:440-446.

Ropiquet, A. and A. Hassanin. 2005. Molecular phylogeny of caprines (Bovidae, Antilopinae): the question of their origin and diversification during the Miocene. Journal of Zoological Systematics and Evolutionary Research 43:49-60.

Schaffer, W. M., and C. A. Reed. 1972. The co-evolution of social behaviour and cranial morphology in sheep and goats (Bovidae, Caprinae). Fieldiana 61:1-88.

Schlosser, M. 1904. Die fossilen Cavicornia von Samos. Beiträge zur Paläontologie und Geologie Österreich-Ungarns und des Orients 17:21-118.

Solounias, N. 1981. The Turolian Fauna from the Island of Samos, Greece, with Special Emphasis on the Hyaenids and the Bovids. Contributions to Vertebrate Evolution 6:1232.

Thenius, E. 1979. Zur systematischen Stellung und Verbreitung von "Gazella" stehlini (Bovidae, Mammalia) aus dem Miozän Europas. Anzeiger der Österreichische Akademie der Wissenschaften Mathematisch-Naturwissenschaftliche Klasse 116:9-13. 
Thomas, H. 1980. Les Bovidés du Miocène supérieur des couches de Mpesida et de la Formation de Lukeino (district de Baringo, Kenya); pp. 82-91 in R.E.F. Leakey and B. A. Ogot (eds.), Proceedings of the 8th Panafrican congress of Prehistory, Nairobi, 1977.

Thomas, H. 1981. Les Bovidés miocènes de la formation de Ngorora du Bassin de Baringo (Rift Valley, Kenya). Proceedings of the Koninklijke Nederlandse Akademie van Wetenschappen 84: 335-410.

Thomas, H. 1984. Les Giraffoidea et les Bovidae miocènes de la formation Nyakach (Rift Nyanza, Kenya). Palaeontographica A 183:64-89.

Vignaud, P., P. Duringer, H. T. Mackaye, A. Likius, C. Blondel, J.-R. Boisserie, L. de Bonis, V. Eisenmann, M.-E. Etienne, D. Geraads, F. Guy, T. Lehmann, F. Lihoreau, N. LopezMartinez, C. Mourer-Chauviré, O. Otero, J.-C. Rage, M. Schuster, L. Viriot, A. Zazzo, and M. Brunet. 2002. Geology and Palaeontology of the Upper Miocene Toros Menalla hominid locality, Chad. Nature 418:152-155.

Vrba, E. S. 1987. New species and a new genus of Hippotragini (Bovidae) from Makapansgat Limeworks. Palaeontologia africana 26:47-58.

Vrba, E. S. and J. Gatesy. 1994. New antelope fossils from Awash, Ethiopia, and phylogenetic analysis of Hippotragini (Bovidae, Mammalia). Palaeontologia africana 31:55-72.

Vrba, E. S and G. B. Schaller. 2000. Phylogeny of Bovidae based on behavior, glands, skulls, and postcrania; pp. 203-222 in E. S. Vrba and G. B. Schaller (eds.), Antelopes, Deer and relatives. Yale University Press, New Haven, Connecticut. 


\section{Captions to figures}

Figure 1. Tchadotragus sudrei, holotype skull, TM12-97-23. A: lateral view; B: dorsal view of the braincase; $\mathbf{C}$ : occipital view; $\mathbf{D}$ : occlusal view of the right tooth-row; $\mathbf{E}$ : ventral view of cranial base (stereo); F: cross-section of right horn-core (anterior side towards the top, lateral to the right); G: lateral view; H: anterior view. Scale bar $=20 \mathrm{~cm}$ for Figs G-H, $5 \mathrm{~cm}$ for Fig. D, 10 cm for all others. [planned for page width]

Figure 2. Sketch-drawing of the holotype skull of Tchadotragus sudrei, to show extent of the lacrymal bone (nasal reconstructed from the left side). Numbers refer to some of the characters listed in Table 6. [planned for column width]

Figure 3. Basal diameters of the horn-cores of the Toros-Menalla hippotragines, of Praedamalis from Lothagam (Harris, 2003), and of modern Hippotragus (mean values, from Klein, 1974). [planned for column width]

Figure 4. A-E: Saheloryx solidus, holotype, TM108-00-08. A: anterior view; B: cross section of right horn-core (anterior side towards the top, lateral to the right); C: occipital view; D: lateral view; E: dorsal view of braincase; F: Tchadotragus sudrei ?, TM266-01-131, occlusal view of lower left tooth-row; G: Hippotragini indet. (Saheloryx solidus ?), TM82-99-02, occlusal and lingual views of lower left tooth-row. Scale bar $=10 \mathrm{~cm}$ for Figs A-E, $5 \mathrm{~cm}$ for Fig. F-G. [planned for page width] 
Figure 5. Cladograms of the Hippotragini. Left : the strict consensus tree (length $=59$; $\mathrm{ci}=66$; ri $=81)$ of the 18 shortest trees (length $=58 ; \mathrm{ci}=67$; $\mathrm{ri}=82$ ); right: the tree preferred here (length $=$ 60; $\mathrm{ci}=66 ; \mathrm{ri}=81$ ). Unambiguous character changes supporting nodes $\mathbf{1}-\mathbf{1 0}$ on both trees are (character numbers are those of Tab. 6): Node $\mathbf{1}=4(1), 9(1), 15(1), 21(1), 22(1), 24(1)$; Node $3=$ 26(1), 28(1), 29(1), 30(1); Node $4=7(1), 16(0), 17(1)$; Node 5 = 18(0), 23(1); Node 7 = 9(0), 21(2); Node 8 = 16(2); Node $9=9(0), 10(1)$; Node $10=2(1), 3(1), 11(2)$. With the early change option, they are further supported by: Node $1=27(1)$; Node $3=1(0)$; Node $4=12(1), 19(1)$; Node $\mathbf{5}=5(1)$. With the late change option, they are supported instead by: Node $3=27(1)$; Node $\mathbf{4}=1(0) ;$ Node $\mathbf{9}=1(0) ;$ Node $\mathbf{1 0}=5(1)$. Other unambiguous changes for the consensus tree are: Node $\mathbf{1}=11(1)$; Node $2=10(1), 25(1)$; Node $5=6(1)$; Node $\mathbf{9}=14(0)$, and for the preferred tree: Node $1=12(0), 19(2) ;$ Node $\mathbf{1}^{\prime}=8(1)$; Node $\mathbf{6}=8(2)$. [planned for column width] 